\title{
Government Collaborative Efforts Supporting Tourism Development in Lesotho
}

\author{
Boitumelo Caroline Rasethuntsa' \\ Lerotholi Polytechnic, School of Enterprise and Management \\ Maseru, Lesotho
}

\begin{abstract}
Many countries strive to establish solid collaborations between the tourism industry players with the belief that knowledge brought by diverse stakeholder team will spill-over across the industry to boost collective productivity. This study focuses on exploring the current established government organisations collaborations geared towards tourism development in Lesotho. The study utilised the interprevististic paradigm using the qualitative research approach. The content analysis based on qualitative interviews with various government tourism related organisations reveal that to some degree, there are existing collaborative efforts among local government organisations, local government and international governments, local government and international bodies, and, local government and the local community. The study also identified that current collaborations are geared towards improving tourists' safety and security, curriculum and skills development, road and air transport infrastructure development, and funding tourism development-related activities. Recommendations for collaborations improvement were presented.
\end{abstract}

Keywords: Tourism, Government Organisations, Tourism Collaborations, Tourism Development, Lesotho

Corresponding author: Boitumelo Caroline Rasethuntsa; E-mail: itumelengcb@yahoo.com DOI: https://doi.org/10.37227/ITHJ-2021-09-348

\section{Introduction}

Tourism is defined as an activity that generates revenue, unites people, stimulates heritage and natural value, and spreads knowledge about the traditional values (Bhat \& Javed, 2013). Several studies have spotted a positive relationship between tourism development and economic growth (Du, Lew \& Ng, 2016). However, due to the COVID 19 pandemic, in the year 2020, the global tourism industry suffered a loss where its contribution to the global Gross Domestic Product (GDP) lowered by 49.1\%; leading to a global total job decline of $18.5 \%$ (World Travel and Tourism Council, 2021; Nyaruwata \& Mbasera, 2021). This indicates that various factors affect tourism performance and some of these factors also include tourism production system, global economy politics, destination characteristics and global socio-cultural environment (Ammirato, Felicetti \& Gala, 2014; 
Sharpley \& Telfer 2015; Horaira \& Devi, 2021). Considering these factors, it is clear that tourism does not operate in isolation, and in order to thrive, it needs a collaborative effort from multiple stakeholders. For example, the private sector plays a vital role in the preparation of space, activities and products even though it has a more profit-oriented development focus (Anuar, Ahmad, Jusoh \& Husaain, 2012). While on the other hand, the public sector is normally charged with the responsibility of ensuring availability of appropriate policies for the sector and standards relating to facilities and services (Cooper, 2012).

For tourism organisations to gain collective competitiveness and effectiveness, it is essential to establish collaborations with other players in the sector (Nguyen, Dong \& Ho: 2021; Adu-Ampong, 2017; Pansiri, 2013; Baggio, 2011). Tourism partnerships are a vital instrument that permit over-all effectiveness of the sector (Gibson, Lynch \& Morrison, 2005), and bring along advantages of information and knowledge sharing and transfer, communication, cooperation, and innovation (Nguyen et al., 2021). The importance of engaging multiple stakeholders in tourism planning and management received a growing recognition in the twentieth century (Mason, 2009). At a local destination level, such partnerships are key and contribute significantly towards sustainable tourism through embracing community and business interests. Local authorities and supporting organisations such as educational bodies also play an essential role in facilitating local tourism innovations through collaborations. This might be the only way to enable the development of some specific initiatives in the long-run (Novelli, Schmitz \& Spencer, 2006). Not only collaborations are essential in local settings; regions seem to be contemplating on collaborations to attain collective efficiency in the tourism trade. For example, some European Union (EU) countries have advocated for a common tourism policy for the region and argue that the problems in the tourism industry can be resolved by putting in place more collaborations and improved coordination mechanisms among EU countries (Juul, 2015). Regional tourism collaborations provide benefits such as offering multiple tour packages to tourists, impact on regional economic development and achieving community engagement (Naipaul, Wang \& Okumus, 2009). However, it has also been identified that trust is an essential element at all tourism collaboration and all participating stakeholders have the duty to harness this factor. More importantly, stakeholders' roles should be clarified, and regular communication be maintained (Park \& Kohler, 2019).

Tourism plays an important role in the Lesotho economy; and it is viewed as a vehicle that can empower women and youth in the country (United Nations Development Programme, 2019). It was perceived that by the year 2020, Lesotho would have developed a quality tourist destination environment and made the tourism industry the biggest national employer and revenue earner (Ministry of Tourism, Sports and Culture, 2000). The National Development Strategic Plan 2012-2016 also stated that the country shall have established a higher global tourism market share by 2016 (Ministry of Finance and Planning, 2012). Regardless of all these plans and government efforts of setting its standards to increase tourism opportunities for the benefit of its populace, tourism in Lesotho has not been thriving (United Nations Development Programme, 2017). According to Yiu, Saner and Lee (2015), Lesotho has a much-undeveloped tourism sector even by African standards, and Lesotho's tourism competitiveness has been ranked far below many African countries.

One of Lesotho's tourism development drawbacks has been noted to be inability to establish collaborations between private sector players and weak partnerships between 
local tourism associations (Rasethuntsa, 2021). The aim of this study therefore, is to explore the degree to which government organisations in Lesotho have established collaborative efforts to advance tourism in Lesotho as it is noted that collaborations and partnerships in tourism accelerates tourism effectiveness. The study is also intended to propose strategies that government structures could employ to build strong tourism related ties to boost tourism competitiveness. The outcome of the study would assist tourism decision-makers to identify some critical areas to focus on when drawing tourism longterm and short-term plans. The study outcome also has the potential to guide other African countries towards tourism collaborations establishment.

\section{Research Deign and Methodology}

A research design is defined as a structure of procedures and techniques used by a researcher to combine numerous elements of research rationally to enable the research problem to be properly handled or how the research can be conducted by utilising a specific methodology (Kumar, 2011; Saunders, Lewis, \& Thornhill, 2012; Bryman \& Bell, 2014). It is also considered as a basic belief system and theoretical framework (Rehman \& Alharthi, 2016) There are three research paradigms namely positivist, interpretivist, and critical paradigm (Kivunja \& Kuyini, 2017). Positivism relates more to the quantitative method, while interpretivism is associated with qualitative research (Al-Habil, 2011). After an assessment of the nature of this research, interpretivism was adopted to guide this study because little is known about the Lesotho tourism industry, and above all, no study can be traced relating to government organisations collaborations dimensions or strategies to improve government organisations tourism partnerships in Lesotho.

The methodology of the study is described regarding the population, sampling process, data collection and analysis methods. A population includes all members of any welldefined set of individuals, events, or objects, while a sample is just a portion of a population (Ary, Jacobs \& Sorensen, 2011). In this study, government tourism-related organisations are regarded as a population. A non-probability sampling, in particular purposive sampling was regarded as the most suitable sampling technique for this study. Purposive sampling is defined as a sampling method dependent on the judgement of the researcher as to who has the best qualities or characteristics to enable the provision of the best information to fulfil the requirements or the objectives of the study (Etikan \& Bala, 2017). To generate primary data, eight government organisations (police, academic institution, air transport and road transport department, Department of Tourism and Culture, Lesotho Tourism Development Corporation, and a government tourist attraction) comprised the sample. The participants were selected based on their role in tourism promotion and work experience in the tourism field and willingness to participate in the study. Table 1 depicts the key informants that participated in the survey. 
Table 1: Participants of the study

\begin{tabular}{|l|l|c|}
\hline \multicolumn{1}{|c|}{ Organisation } & \multicolumn{1}{|c|}{ Purpose of selection } & \multicolumn{1}{c|}{$\begin{array}{c}\text { Number of } \\
\text { participants }\end{array}$} \\
\hline Department of Civil Aviation & Air transport infrastructure & 1 \\
\hline Department of Roads & Road transport infrastructure & 1 \\
\hline Tourist attraction & Natural resource tourist attraction & 1 \\
\hline Department of Culture & Culture and heritage governance & 1 \\
\hline Department of Tourism & Tourism industry governance & 1 \\
\hline Crime Prevention Unit & General safety and security & 1 \\
\hline $\begin{array}{l}\text { Lesotho Tourism Development } \\
\text { Corporation (LTDC) }\end{array}$ & $\begin{array}{l}\text { Tourism investment promotion, } \\
\text { marketing and research }\end{array}$ & 1 \\
\hline Lerotholi Polytechnic & $\begin{array}{l}\text { Tourism curriculum and skills } \\
\text { development }\end{array}$ \\
\hline
\end{tabular}

From Table 1, it could be noted that eight participants selected to participate in the study. These organisation offers tourism related services inclusive of security, education, policy and governance, tourism promotion and marketing, tourist attraction services, and transport infrastructure.

Data collection in research can either be through primary- secondary and tertiary data collection means (Blaikie, 2009). Primary data was collected by conducting in-depth interviews using a semi-structured interview guide with the eight participants. The interview guide elicits information about the biographical profile of the key informants, information pertaining to the organisations they are employed in, the organisational level of involvement in tourism activities, and tourism development issues.

Data analysis is the fundamental and a significant element in qualitative research because it generates large information through field notes, interview recordings and transcripts, among others (Bryman \& Bell, 2014). All participants voluntarily signed the consent form and information regarding their rights, the objective of the research, and assurance of their anonymity prior to interviews. Immediately after interviews, the data was transcribed. Each transcription was allocated and assigned (G1 to G8). This coding strategy was utilised to maintain interviewee anonymity so that none of them can be linked to any information.

The qualitative data must be arranged to allow data clarity (Walliman, 2011). Content analysis was used to analyse the data. With relevance to this, the researcher read through the data, noted meanings and made a distinction between which pieces of data to keep, and which to discard. Data were then explored to identify themes and patterns of the information on hand. Qualitative researchers would normally avoid using the terms, validity and reliability, and opt for trustworthiness inclusive of credibility, trustworthiness, dependability, confirmability, and transferability (Marshall \& Rossman, 2011; Bryman \& Bell, 2014). To attain credibility in this study, data source triangulation was ensured in the collection of data through interviews with different government organisations as well as comparing the interviews data with literature sources.

To attain dependability, an inspection of field notes was performed to ensure that the right participants were interviewed, appropriate analysis techniques were used, and 
ethics requirements were adhered to. Confirmability refers to the extent to which the results of the research can be confirmed by other researchers and also relates to establishing that data and interpretations of the results are not figments of the researcher's imagination but derived from the data (Korstjens \& Moser, 2018). To ensure confirmability, a cumulative audit trail was constructed from interviews to observations where the researcher used the strategy to check and recheck the data during the entire research. Information on the current tourism practices and joint tourism efforts was analysed to establish areas of improvement and to provide more understanding of the current operating systems of the Lesotho tourism industry. An in-depth analysis by comparing the results of the different participants with each other contributed towards some transferability, as this study used rich and well-detailed descriptions to convey the findings.

\section{RESULTS AND DISCUSSIONS}

The content analysis identified four main themes, namely local inter-governmental alliances, local government with international governments alliances, local government with international bodies alliances, local government with communities' alliances were identified. The next discussion shall provide these in detail.

\section{Theme 1: $\quad$ Local inter-governmental alliances}

Local government with local government alliances includes government ministry relationships with other government organisations, public tertiary institutions with government organisations, and government parastatal organisations with other government organisations.

\section{i) Tertiary Education Institution and the LTDC}

The Tertiary Education Institution's collaborating relationship with the Lesotho Tourism Development Corporation about the grading of accommodation establishments. As noted by this participant:

G1: We are partaking in the Hotel Star Grading Board with the Lesotho Tourism Development Corporation.

\section{ii) The Tertiary Education Institution and the Ministry of Education and Training}

The Tertiary Education Institution collaborates with the Ministry of Education and Training regarding curriculum development programmes. As noted by this participant:

G1: Serving at the National Curriculum Development Centre to develop the curriculum of tourism subjects at high school level and in TVET institutions. We conduct career guidance for high school students in tourism discipline throughout the country.

\section{iii) The Tertiary Education Institution and the Department of Tourism}

The Tertiary Education Institution has working collaborations with the Department of Tourism on issues relating to curriculum development and development of short-term programmes. As noted by this participant:

G6: .... The initiative is going to focus on the development of a new tourism curriculum at the Lerotholi Polytechnic and development of on-going short-term training programmes for people already engaged in the tourism industry. 
iv) Ministry of Tourism, Environment and Culture (MTEC) alliance through the Bilateral Security Working Group

Through this working group, the Ministry of Tourism, Environment and Culture (MTEC) collaborates with the Crime Prevention Unit, Lesotho Defence Force, and the Directorate of Corruption and Economic Offences. This alliance is specifically focusing on improving safety and security of tourists and ensuring that nature is not destroyed in Lesotho. As noted by this participant:

G2: We are a member of the Bilateral Security Working Group with organisations inclusive of the National Security Services, Lesotho Defence Force, Ministry of Tourism, Environment and Culture, and Directorate of Corruption and Economic Offences. This workgroup mandate is to assure safety and security and ensure that places of interest are not damaged, tourists are safe.

\section{v) MTEC and with the Department of Public Works}

According to the Department of Public Works, there are tourism alliances between MTEC and their department regarding the provision of roads, as this is an essential requirement for tourism wellbeing. As noted by this participant:

G5: In tourism, we only have a relationship with the Ministry of Tourism, Environment and Culture. That's how it has to be. We cannot have relationships with individual organisations.

vi) MTEC and LTDC

It further emerged that the MTEC has a collaborating relationship with LTDC based on budget allocation to implement their plans. LTDC depends fully on government budget and it is an implementation arm of MTEC. As noted by this participant:

G7: The Ministry of Tourism, Environment and Culture communicates on our behalf at a ministerial- level for financial resources.

\section{vii) Department of Tourism and Ministry of Trade and Industry}

The Department of Tourism has a relationship with the Ministry of Trade and Industry whereby they act as their middleman to obtain funding from the African Development Bank through the Ministry of Trade and Industry for tourism curriculum development and short-term tourism training. As noted by this participant:

G6: We are in talks with the African Development Bank through Private Sector Competitiveness Project to establish the School of Excellence to address the skills shortages within the tourism industry. Ministry Tourism, Environment and Culture, Lerotholi Polytechnic, and Lesotho Tourism Development Corporation have met to discuss a technical proposal from one of the consultants who will be engaged to do a situation analysis and a feasibility study.

\section{viii) Department of Tourism and the Department of Civil Aviation}

About air transport infrastructure driven matters, the Department of Tourism has a collaborative relationship with the Department of Civil Aviation in terms of continuous tourism development support and regard their input as important for policy development. As noted by this participant: 
G3: We have a standing committee with the Department of Tourism which meets quarterly to look at how the civil aviation can support tourism development. The Department of Tourism also invited us when developing the tourism policy.

\section{ix) Department of Tourism and the Ministry of Finance}

The Department of Tourism also has a collaborating relationship with the Ministry of Finance whereby they serve as a body that secures international funding for road infrastructure provision, in particular for road signage. As noted by this participant:

G6: With the roads department, we are aware that poor road conditions in the country have a negative impact on tourism. We have managed to secure funding from the Lesotho Millennium Development Agency to improve road signage.

\section{x) Department of Tourism and the Crime Prevention Unit}

The Department of Tourism has working alliances with the Crime Prevention Unit to ensure safety and security for tourists and the joint task of issuing business licenses. To promote tourists' safety and security, the Department of Tourism educates the police of tourism issues to prepare the police for promotion of tourism safety and security exercises that the police have with the general public. Though the Department of Tourism further noted that this is not their responsibility but LTDC's.

G6: We collaborate with the police department for issuance of licenses, their role here is to certify the security status..... and when the tourists have been attacked, though this is LTDC's responsibility......... we teach police staff about tourism so that they can also hold public gatherings to teach people, still responsibility of LTDC.

\section{xi) The Crime Prevention Unit alliances through the Maluti Drakensburg} Transfrontier Project

It was noted that the Crime Prevention Unit through the Maluti Drakensburg Transfrontier Project has tourism-led relationships with multiple partners including the Lesotho Defence Force, South African Police Service and the South African Defence Force. This working team ensures the creation of conducive tourism safety and security environment between South Africa and Lesotho borders and oversees the protection of wildlife. As noted by this participant:

G2: Again, through the Maluti Drakensburg Transfrontier Project, the Lesotho Police Mounted Services and Lesotho Defence Force do have scheduled meetings with the SA Police Service and Defence Force to discuss issues related to safety and security of tourists along that protected area and also means of protecting wildlife across the protected area.

\section{xii) The LTDC with the Crime Prevention Unit alliances}

The LTDC has working relationships and seems to have alliances with the police through joint tourism safety and security information dissemination programmes targeted to the general public. As noted by this participant:

G7: We do hold public gatherings with the police to sensitise community regarding the importance of tourists and how to treat them.

It appears that many government organisations have established working tourism alliances amongst themselves. The Tertiary Education Institution has an alliance with the 
Department of Tourism, Ministry of Education and Training, and LTDC relating to the development of the necessary tourism skills by offering applicable curriculum content and the hotel grading exercise. According to Anderson (2015), in Tanzania, the government has proposed working collaborations with the academic sector in areas of accreditation of tourism courses, infrastructure development and capacity building. This indicates that such collaborations had also been used in some African countries to promote tourism development.

The Crime Prevention Unit has established tourism-led collaborations with the Ministry of Tourism, Environment and Culture, LTDC, Lesotho Defence Force, and Directorate of Corruption and Economic Offences based on improving tourists' safety and security in Lesotho. The status of safety and security influences a country's tourism competitiveness (Kovari \& Zimanyi, 2011) and it is recommended that this issue should be treated as a crucial condition of tourism. This is because tourists are unlikely to enter unsafe destinations (Van Vuuren, 2016).

The Department of Tourism appeared to value local alliances the most as they partner with the Department of Public Works and Civil Aviation to ensure that general air and road infrastructure is in place for tourists to visit the country and involves them in policy development. Collaborations with air transport infrastructure providers are crucial as it was established that air transport demand has been highly increasing to transport passengers from country to country (Zajac, 2016); the number of air transport users has increased by $38.6 \%$ between the years 2008 to 2017 (International Civil Aviation Organisation, 2017). The Department of Tourism further works with the LTDC, which is an implementation organisation for tourism development initiatives. Similarly, the Mauritian government also established the Mauritius Tourism Promotion Authority to implement tourism activities such as tourism promotion and exploitation of niche markets (Mauritius Ministry of Tourism, 2018). Due to the mandate of the LDTC, it is natural that it would have alliances with all the departments of the Ministry of Tourism, Environment and Culture as environment and culture appears to be Lesotho's tourism attractions while the Department of Tourism develops general tourism policies.

The Department of Tourism also appears to have formed alliances with the Ministry of Trade and Industry to organise funding on behalf of tertiary education tourism programme development through the Private Sector Competitiveness Project, and the Ministry of Finance to provide funding to improve road signage worthwhile to ease visitors' travelling via the Lesotho Millennium Development Agency. Government-togovernment tourism collaborations are intended to provide unified one-stop services and to provide efficient use of government resources at national or departmental levels (Kalbaska, Janowski, Estevez \& Cantoni, 2016).

\section{Theme 2: Local government with international governments alliances}

The Department of Civil Aviation has alliances with international governments such as Rwanda, Qatar and the United Arab Emirates to expand Lesotho's air transport's services. Also, the Department of Civil Aviation. As noted by this participant:

G3: We have signed agreements with the government of Rwanda, Quarter, and the $U A E$, that their airlines can fly to Lesotho and airlines registered in Lesotho can fly to these countries. 


\section{Theme 3: Local government with international bodies alliances}

The Department of Tourism has a collaborating relationship with the United Nations World Tourism Organisation on improving parks management systems. The Department of Civil Aviation also works with the International Civil Organisation and the Africa Civil Organisation for standardisation of the aviation services and training. As noted by the participant:

G6: International bodies, World Tourism Organisation, currently they are conducting a feasibility study of some parks so that we can have a map on how to develop them to be at proper standards and how we can transfer them to private sector for management.

G3: We are a Member of the International Civil Organisation and the Africa Civil Organisation. This is mainly concerned with maintaining standards and offering training.

The Department of Civil Aviation and Tourism has collaborations with international governments. The Department of Aviation has a government alliance with two airlines, namely Air Rwanda and Air Qatar of the United Arab Emirates, as well as with the African and International Civil Aviation Organisation. In comparison, in Mauritius, 24 Airlines from different regions across the world have successfully been engaged in Mauritian aviation (Mauritius Airport, 2018). This affirmed the perspectives of the United Nations Conference on Trade and Development (2013) that Lesotho has not prioritised tourism linkages at an international level. The Egyptian government has successfully utilised international government to government collaborations as a strategy to promote aviation and accommodation services among others (Oxford Business Group, 2018).

A working group has been established with the Department of Tourism, Lesotho Defence Force, and the Directorate of Corruption and Economic Offences with the South African government through the South African Police Services and South African Defence Force. The aim of this effort is to work on the improvement of tourists' safety and security and protection of biodiversity along the borders of Lesotho and South Africa. International government-to-government safety and security alliances have been established by both the Australian and the United States government; this resulted in a high safety and security condition that has also influenced a high economic performance in Australia (Department of the Prime Minister and Cabinet, 2013). Government-to-government international tourism alliances extend beyond safety and security issues; for example, the government of Tanzania worked with other East-African countries to ensure good hotel grading standards (Tairo, 2012). This shows that government to government international tourism security and safety alliances could benefit all countries involved.

The Department of Tourism also has an alliance with the World Tourism Organisation. Juul (2015) advocated forming international alliances to solve tourism challenges and to improve tourism performance as was demonstrated by the European Union that propose for the development of common tourism policy in their region. For example, to assure tourism development, Israel has affiliated with the Adventure Tourism Research Association, Asia Pacific Tourism Association, Association for Promotion of Tourism to Africa, Association for Tourism and Leisure Education, European Tourism Association, International Association for Tourism Economics, International Coalition of Tourism Partners, Tourism 2030, World Federation of Tourist Guide Associations, World Tourism Organisation, and World Travel and Tourism Council (Israel Science and 
Technology Directory, 2021). This indicates that international collaborations to advance tourism is a crucial step that has already been adopted by individual countries and regions.

\section{Theme 4: $\quad$ Local government with communities}

It seems the Department of Culture has a collaborating relationship with the community in policy design and on cultural heritage matters. As noted by a participant:

G4: With regard to tangible cultural heritage resources, the department works with the community on matters relating to the management of cultural heritage. Also, work with art groups to ensure smooth operations for cultural heritage organisations. We are currently reviewing the cultural heritage policy in collaboration with all the stakeholders.

The Crime Prevention Unit seems to have tourism led alliances with the communities through their tourism safety and security information dissemination programmes. As noted by this participant:

G2: We hold public gatherings upon tourist attack reports, when tourists are attacked or when wildlife is being destroyed. Normally the reports would come from tourists reporting these crimes or citizens reporting or the department of tourism.

The Department of Culture appears to have established tourism-led collaborations with the general community regarding cultural heritage preservation to promote sustainable tourism. Kalbaska, et al. (2016) highlighted the importance of governments forming alliances with the community as this promotes exchange of information, and according to Spenceley, Rylance, Nanabhay, and Van der Watt (2016), this information could relate to areas such as services, infrastructure, plans or financial support from the government to the community. Furthermore, Roseland, (2000) and Monkelbaan, (2019) emphasised that it is the role of the government to capacitate the community to become actors of sustainable tourism. The effectiveness of community alliances can be seen in the examples set by the Tanzania Tourist Board and their Ministry of Natural Resources and Tourism to coordinate community-based tourism programmes to ensure community buy-in in tourism developmental activities (Tanzania Cultural Tourism Programmes, 2018). It emerged that the Crime Prevention Unit has also established tourism-led collaborations with the general community through tourism safety and security promotion campaigns. The police and community working collaborations emerged as the major strategic complement to traditional policing practices where the police and the communities actively work together in problem-solving in specific areas such as prevention and detection of crime (Organisation for Security and Co-operation in Europe, 2008). This shows that the government collaborations with the local community could have a positive impact on tourism development.

\section{Conclusions}

The objective of this study was to identify the current established government organisations collaborations geared towards tourism development in Lesotho. The study utilised the interprevististic paradigm using the qualitative research approach. It can be concluded that there is a high degree of tourism-led collaborations between government organisations invested towards improving tourists' safety and security, curriculum and skills development, road and air transport infrastructure development, and funding tourism development-related facilitation. However, it was noted that there are few international 
partnerships established between the government organisations and international governments and bodies, which may greatly contribute to Lesotho's tourism development. Community alliances have also been neglected in Lesotho as only the Department of Culture and the Crime Prevention Unit have tourism-led collaboration through information dissemination exercises in areas such as cultural heritage protection.

\section{Recommendations}

To improve local government collaborations, it is recommended the following strategies could be adopted:

- MTEC to consider membership with various international tourism bodies such as the Association for Promotion of Tourism Africa, International Coalition of Tourism Partners, and the International Association for Tourism Economics. For example, MTEC can learn best practices and be knowledgeable on expected international tourism standards to guide Lesotho's tourism organisations as well as assisting other government organisations to acquire membership in related international tourism organisations such as the Association for Tourism and Leisure Education, and the World Federation of Tourists Guide Association;

- LTDC to encourage the establishment of community-based-tourism projects to involve the community in tourism activities and improve their livelihood through opening new revenue streams. This could be through selling traditional food near tourist attractions to introduce tourists to local cuisine or open small souvenir shops near places of interest, and

- LTDC to establish a Community Tourism Association to serve as an umbrella body that brings together and advocates for the interests of the community in Lesotho to ensure that local people benefit from tourism such as employment opportunities offered by tourism and eliminate value chain leakages. LTDC could help the community through this association to spot business opportunities such as training them to become site guides or offer homestay accommodation for tourists to experience local culture.

The adoption of these recommendations could have a positive impact on tourism development in Lesotho and assist the government in realising its tourism vision. Apart from this, other developing countries especially in the African region could also adopt these recommended strategies to advance their tourism sectors as well.

\section{Research Limitations and Future Directions}

This study has managed to contribute to the African tourism literature by adding new knowledge relating to government organisations structure of collaborations geared towards tourism development. The study only focused on the government organisations collaborations; however, the research did not go into details on the factors that prohibit collaborations establishment and effectiveness. Future research could therefore concentrate on establishing the drawbacks prohibiting government organisations in establishing tourism development collaborations. A study in this area could guide government decision makers on the strategic areas that need urgent attention to enable tourism development collaborations to properly function. 


\section{References}

Adu-Ampong, E. (2017). Divided we stand: institutional collaboration in tourism planning and development in the Central Region of Ghana. Current Issues in Tourism, Current Issues in Tourism, 20 (3):295-314.

Al-Habil, W. I. (2011). Positivist and phenomenological research in American public administration. International Journal of Public Administration, 34(14):946-953.

Ammirato, S., Felicetti, A. M. \& Della Gala, M. (2014). Tourism destination management: A collaborative approach. In Working Conference on Virtual Enterprises (217-226). Springer, Berlin, Heidelberg.

Anderson, W. (2015). Human resources needs and skills gap in the tourism and hospitality sector in Tanzania. Available: http://hat-tz.org/hattzorg/wpcontent/uploads/2015/05/Human-Resource-Needs-and-Skill-Gaps-in-the-Tourismand-Hospitality-Sector-in-Tanzania.pdf. [Accessed: 16 April 2021].

Anuar, A. N. A., Ahmad H., Jusoh, H. \& Hussain, M. Y . (2012). Understanding the role of stakeholder in the formation of tourist friendly destination concept. Journal of Management and Sustainability, 2(2):69-74.

Ary, D., Jacobs, L. C. \& Sorensen, C. (2010). Introduction to research in education. $8^{\text {th }}$ Edition. Belmont: Wardsworth.

Baggio, R. (2011). Collaboration and cooperation in a tourism destination: A network science approach. Current Issues in Tourism, 14(2):183-189.

Bhat, Z. A. \& Iqbal, J. (2013). Scope and need of privatisation of tourism in north India with special reference to J\&K. Commerce and Management, 2(5):134-142.

Blaikie, N. (2009). Designing social research. $2^{\text {nd }}$ Edition. Cambridge: Polity Press.

Bryman, A. \& Bell, E. (2014). Research methodology: Business and management contexts. Cape Town: Oxford University Press Southern Africa.

Camilleri, M. A. (2018). The tourism industry: An overview. In Travel marketing, tourism economics and the airline product. Chem, Switzerland: Springer Nature.

Cooper, C. (2012). Essentials of tourism. Harlow: Pearson Financial Times Prentice Hall.

Department of the Prime Minister and Cabinet. (2013). A Strong and Secure Strategy for Australia National Security. Available: https://www.files.ethz.ch/isn/167267/Australia\%20A\%20Strategy\%20for\%20National \%20Securit.pdf [Accessed: 17 April 2021].

Du, D., Lew, A. A. \& Ng, P. T. (2016). Tourism and economic growth. Journal of Travel Research, 55(4):454-464.

Etikan, I. \& Bala, K. (2017). Sampling and sampling methods. Biometrics and Biostatistics International Journal, 5(6):1-3.

Gibson, L., Lynch, P.A. \& Morrison, A. (2005). The local destination tourism network: Development issues. Tourism and Hospitality Planning \& Development, 2(2):87-99.

Horaira, M. A., \& Devi, A. (2021) Cultural Tourism in Bangladesh, a Potential and Profound Tourism Destination: Developing a Model for Cultural Tourism Development in Bangladesh. International Tourism and Hospitality Journal, 4(10): 122.

International Civil Aviation Organisation. 2017. Annual Report 2017 Air Transport Statistics. Montreal: International Civil Aviation Organisation.

Israel Science and Technology Directory, (2021). Tourism: International Associations. Available: $\quad$ https://www.science.co.il/tourism/International-associations.php. [Accessed: 26 April 2021]. 
Juul, M. (2015). Tourism and the European Union: Recent Trends and Policy Development. Brussels: European Parliamentary Research Services.

Kalbaska, N., Janowski, T., Estevez, E. \& Cantoni, L. (2016). E-Government relationships framework in the tourism domain. A first map. In Inversini A. \& Schegg R. (Eds). 2016. Information and Communication Technologies in Tourism. New York: Springer.

Kivunja, C. \& Kuyini, A. B. (2017). Understanding and applying research paradigms in educational contexts. International Journal of Higher Education, 6(5):26-41.

Korstjens, I. \& Moser, A. (2018). Series: Practical guidance to qualitative research. Part 4:

Trustworthiness and publishing. European Journal of General Practice, 24(1):120124.

Kovari, I. \& Zimanyi, K. (2011). Safety and security in the age of global tourism (The changing role and conception of safety and security in tourism). Apstract: Applied Studies in Agribusiness and Commerce, 5:59-61.

Kumar, R. (2011). Research methodology: A step-by-step guide for beginners. London: Sage.

Marshall, C. \& Rossman, G. B. (2011). Designing qualitative research. $5^{\text {th }}$ Edition. Thousand Oaks: Sage.

Mason, P. (2009). Tourism impacts, planning and management. $2^{\text {nd }}$ Edition. Oxford: Butterworth-Heinemann.

Mauritius Airport. (2018). Airlines. Available: https://mauritiusairport.atol.aero/passengers/flights/airlines. [Accessed: 17 April 2021].

Mauritius Ministry of Tourism. 2018. Mauritius Tourism Promotion Authority. Available: http://tourism.govmu.org/English/Authorities\%20and\%20Board/Pages/MauritiusTourism-Promotion-Authority.aspx. [Accessed: 26 April 2021].

Ministry of Finance and Development Planning. (2012). National Strategic Development Plan: Growth and development strategic framework 2012-2017. Maseru: Government Printing.

Ministry of Tourism, Sports and Culture. (2000). The Kingdom of Lesotho National Tourism Policy. Maseru: Government Printing.

Monkelbaan, J. (2019). Governance for the sustainable development goals. Singapura: Spinger.

Naipaul, S., Wang, Y., \& Okumus, F. (2009). Regional destination marketing: a collaborative approach. Journal of Travel and Tourism Marketing, 26(5-6):462-481.

Nguyen, T. Q. T., Dong, X. D., \& Ho, T. (2021). Stakeholder Involvement in Destination Marketing: A Network Analysis of two Destinations in Vietnam. Tourism and Hospitality Management, 27 (1):189-203.

Novelli, M., Schmitz, B. \& Spencer, T. (2006). Networks, clusters and innovation in tourism: A UK experience. Tourism management, 27(6):1141-1152.

Nyaruwata, S., \& Mbasera, M. (2021). A critique of contribution of tourism to jobs in southern african development community (SADC): Implications for post COVID-19 pandemic. International Tourism and Hospitality Journal, 4(5), 1-18.

Organisation for Safety and Security in Europe. (2008). Good Practices in Building PolicePublic Partnerships. Vienna: Organisation for Security and Co-operation in Europe.

Oxford Business Group. (2018). Egypt Sees Growth in Visitors' Numbers and Tourism Revenue. London: Oxford Business Group. 
Pansiri, J. (2013). Collaboration and partnership in tourism: The experience of Botswana. Tourism Planning and Development, 10(1):64-84.

Park, S. \& Kohler, T. (2019). Collaborations for sustainable tourism through strategic bridging: A case of travel12change. Journal of Vacation Marketing, 25(1):99-110.

Rasethuntsa, B. C. (2021). The Dimensions of tourism businesses- and associations collaborations to promote tourism development Lesotho. International Journal of Academic Research in Business and Social Sciences, 11(9):392-406.

Rehman, A. A. \& Alharthi, K. 2016). An introduction to research paradigms. International Journal of Educational Investigations, 3(8):51-59.

Roseland, M. (2000). Sustainable community development: integrating environmental, economic, and social objectives. Progress in planning, 54(2), 73-132.

Saunders, M., Lewis, P. \& Thornhill, A. (2012). Research methods for business students. $6^{\text {th }}$ Edition. Harlow: Pearson Professional Limited.

Sharpley, R. \& Naidoo, P. (2010). Tourism and poverty reduction: The case of Mauritius. Tourism and Hospitality Planning and Development, 7(2):145-162.

Spenceley, A., Rylance, A., Nanabhay, S. \& van der Watt, H. (2016). Operational guidelines for community-based tourism in South Africa. Department of Tourism: Republic of South Africa.

Tairo, A. (2012). 'Hotel grading in Tanzania set for second phase,' Global Travel Industry News, 24 August 2012. Available: https://www .eturbonews.com/60180/hotel-gradingtanzania-set-second-phase. [Accessed: 22 April 2021].

Tanzania Cultural Tourism Programmes. (2018). Background of cultural tourism in Tanzania. Available: http://www.tanzaniaculturaltourism.com/history.htm. [Accessed: 16 May 2021].

United Nations Conference on Trade and Development. (2013). Services Policies Review of Lesotho. Geneva: United Nations Conference on Trade and Development.

United Nations Development Programme. (2017). Lesotho Country Analysis Working Document Final Draft. New York: United Nations Development Programme.

United Nations Development Programme. (2019). National Development Strategic Plan 2018/19-2022/23. New York: United Nations Development Programme.

Van Vuuren. I. (2016). The changing concept of safety and security in tourism. Available: https://tourismsafety.tbcsa.travel/wp-content/uploads/2016/03/INFOSUM04.2016.pdf. [Accessed: 22 April 2021].

Walliman, N. (2011). Research methods: The basics. London: Routledge Taylor and Francis Group.

World Travel and Tourism Council. (2021). Travel and Tourism: Economic Impact 2021. London: World Travel and Tourism Council.

Yiu, L., Saner, R. \& Lee, M. R. (2015). Lesotho, a tourism destination: An Analysis of Lesotho's current tourism products and potential for growth. In Camillo, A. A. 2015. Handbook of research on global hospitality and tourism management, Harshey: IGI Global.

Zajac, G. (2016). The Role of Air Transport in the Development of International Tourism. Journal of International Trade, Logistics and Law, 2(1):1-8. 